\title{
Hegemoni dan Ekonomi Politik Dana Keistimewaan di Daerah Istimewa Yogyakarta

\author{
Hegemony and Political Economy of Privileged Fund in Special Region of Yogyakarta
}

\author{
Anggalih Bayu Muh Kamim* \\ *Alumnus Departemen Politik Eु Pemerintahan FISIPOL UGM \\ email: *anggalih.bayu@yahoo.co.id
}

\begin{tabular}{l} 
Riwayat Artikel \\
\hline Diterima: 23 Juli 2021 \\
Direvisi: 23 September 2021 \\
Disetujui: 1 Oktober 2021 \\
doi: $10.22212 /$ jp.v12i1.2483
\end{tabular}

\section{Abstract}

The Privileged Fund is used to financing five affairs, namely, spatial planning, land, culture, institutions and procedures for filling the positions with governor and vice governor. Various problems such as low participation, institutional problems and the interests of local authorities were identified as the cause of the Privileged Fund not being able to increase welfare. This study looks at the hegemonic perspective to show the consolidation of the ruling class since the promulgation of the Privileged Law until its implementation has an impact on the inability of the community to control the Privileged Fund. This study is a qualitative research with a case study approach. Data was collected through documentation techniques, in-depth interviews and Focus Group Discussions. Data analysis was carried out starting from extracting the problem to drawing conclusions. The results of the study show that the mass action that emerged in support of the Privileged Law did not originate from the aspirations of the citizens, but rather a form of the success of the local ruling class in strengthening the social base. The hegemony of the ruling class plays important roles in preventing the growth of critical awareness from the grassroots community and inhibits organic intellectuals from overseeing the Privileged Fund. Organic intellectuals have not been able to build alternative education and build movement alliances. The ruling class is able to mobilize resources and government structures to keep up its hegemony in the use of the Privileged Fund in the Special Region of Yogyakarta.

Keywords: Hegemony; Priveleged Fund; Counter Hegemony; Organic Inttelectuals

Abstrak

Dana Keistimewaan digunakan untuk membiayai lima urusan yakni, tata ruang, pertanahan, kebudayaan, kelembagaan dan tata cara pengisian jabatan gubernur dan wakil gubernur. Berbagai permasalahan seperti rendahnya partisipasi, masalah institusional dan kepentingan pennguasa lokal teridentifikasi menjadi penyebab Dana Keistitmewaan belum mampu membawa peningkatan kesejahteraan. Kajian ini melihat dengan perspektif hegemoni untuk menunjukan konsolidasi kelas penguasa sejak pengusulan Undang-Undang Keistimewaan sampai pelaksanaannya berdampak pada ketidakmampuan masyarakat mengawal pemanfaatan Dana Keistimewaan. Kajian ini adalah penelitian kualitatif dengan pendekatan studi kasus. Pengumpulan data dilakukan melalui teknik dokumentasi, wawancara mendalam dan Focus Group Discussion. Analisis data dilakukan mulai dari penggalian masalah sampai dengan penarikan kesimpulan. Hasil kajian menunjukan aksi massa yang muncul dalam mendukung Undang-Undang Keistimewaan bukanlah berasal dari aspirasi warga, melainkan bentuk keberhasilan kelas penguasa lokal dalam memperkuat basis sosial. Hegemoni kelas penguasa berperan erat dalam mencegah tumbuhnya kesadaran kritis dari masyarakat di akar rumput dan menghambat intelektual organik dalam mengawal penggunaan Dana Keistimewaan. Para intelektual organik belum mampu membangun pendidikan alternatif dan membangun aliansi gerakan. Kelas 
penguasa mampu memobilisasi sumber daya dan struktur pemerintahan untuk mempertahankan hegemoninya dalam pemanfaatan Dana Keistimewaan di Daerah Istimewa Yogyakarta.

Kata Kunci: Hegemoni; Dana Keistimewaan; Konter Hegemoni; Intelektual Organik

\section{Pendahuluan}

Dana Keistimewaan Daerah Istimewa Yogyakarta (Danais DIY) dikucurkan sejak tahun 2013 dengan tujuan untuk meningkatkan kesejahteraan masyarakat. Hal tersebut menjadi amanat dari UndangUndang Nomor 13 Tahun 2012 pasal 5 huruf $\mathrm{b}$ yang menjadi penanda bahwa penerapan urusan-urusan Keistimewaan DIY bermuara pada upaya peningkatan kemakmuran rakyat. Keistimewaan DIY sendiri meliputi lima urusan, yakni kebudayaan, tata ruang, pertanahan, kelembagaan dan tata cara pengisian jabatan gubernur dan wakil gubernur yang pelaksanaannya dibiayai dengan Danais. Kajian mendalam untuk memastikan bahwa Danais digunakan sepenuhnya untuk peningkatan kesejahteraan masyarakat menjadi penting disebabkan dorongan munculnya UUK DIY tidak lepas dari peran serta rakyat kecil.

Beberapa kajian telah mencoba mengambarkan dampak pengucuran Danais dalam peningkatan kesejahteraan masyarakat beserta berbagai hambatan dalam pelaksanaannya. Arum \& Wijaya (2021) menunjukan bahwa adanya Danais telah membuat indeks pembangunan manusia dan indeks kesejahteraan sosial Kabupaten Bantul meningkat sejak tahun 2012. Rakyat DIY dianggap telah memiliki pemahaman yang baik mengenai adanya inventarisasi tanah Kasultanan dan Pakualaman dengan pembiayaan dari Danais akan mendorong peningkatan kesejahteraan. ${ }^{1}$

1 Halimatus Fadilah Sekar Arum and Sakir Ridho Wijaya, "Pengaruh Dana Keistimewaan Yogyakarta Terhadap Kesejahteraan Masyarakat Di Kabupaten Bantul,” Jurnal Politikom Indonesiana: Kajian Ilmu Pemerintahan, Ilmu Politik Dan Ilmu Komunikasi 6, no. 1 (2021): 71-80.
Temuan Sakir \& Mutiarin (2015) justru menunjukan hasil sebaliknya, di mana penggunaan Danais DIY pada tahun 2013-2015 belum berjalan maksimal. Beberapa masalah yang teridentifikasi, yakni prioritas dana yang dominan untuk urusan kebudayaan; pemda belum melihat sejauhmana kemampuan dalam mencapai target program tiap urusan keistimewaan; penyerapan dana yang tidak berjalan baik; tidak adanya identifikasi output dan outcome secara jelas. ${ }^{2}$ Kendala institusional seperti kekurangan pegawai, partisipasi masyarakat yang belum dilibatkan sejak dari proses pengusulan sampai evaluasi dan ketidaksiapan pengguna anggaran menjadi penyebab masalah yang ada dalam penggunaan Danais.

Efendi, Sanahdi, dan Putra (2017) juga menemukan bahwa penggunaan Danais dari tahun 2013 sampai 2015 belum menunjukan efek pada perbaikan kesenjangan sosial di DIY. Beberapa sebab yang menyebabkan penggunaan Danais pada 2013-2015 belum berjalan dengan baik disebabkan oleh fenomena partisipasi rakyat kecil yang rendah; kecenderungan dari penguasa lokal untuk meletakan hak istimewa bukan kepada masyarakat; dan ketidakjelasan penerima manfaat dari dana keistimewaan. ${ }^{3}$ Tanjung, Mutiarin dan Purnomo (2018) menjelaskan bahwa peningkatan anggaran Danais selama

2 Sakir and Dyah Mutiarin, "Kebijakan Anggaran Dana Keistimewaan Daerah Istimewa Yogyakarta," Jurnal Ilmu Pemerintahan $\mathcal{E}$ Kebijakan Publik 2, no. 3 (2015): 471-485.

3 David Effendi, Rifki Sanahdi, and Agus Andika Putra, "Big Budget, Low Impact: An Alternative Evaluation On Benefit And Impact Of Special Fund In Di Yogyakarta, 2013-2015," Journal of Government and Politics International Conference II, no. X (2017): 269. 272. 
2013-2017 sayangnya masih dibayangi permasalahan pelik. Dua permasalahan yakni, monitoring dan evaluasi yang tidak transparan dan tidak melibatkan masyarakat serta pengelolaan urusan kebudayaan yang belum berjalan dengan baik. ${ }^{4}$

Satriawan(2017) memaparkan penggunaan Danais pada 2013-2017 masih menghadapi masalah yang terulang, yakni ketidakmampuan pemda untuk membuat target tiap urusan sesuai kemampuan lembaga masing-masing. Masyarakat juga belum ditempatkan secara jelas sebagai penerima Danais pada tahun anggaran 2013-2017. Hal tersebut disebabkan urusan kebudayaan sebagai sektor dengan porsi pembiayaan paling besar dari Danais terbatas pada program yang bersifat seremonial. ${ }^{5}$ Sukirno dan Kuncahyo (2015) menjelaskan bahwa campur tangan pemerintah pusat turut menghambat pemanfaatan Danais dalam upaya peningkatan kesejahteraan. Hal tersebut disebabkan adanya masalah keterlambatan dan perubahan peraturan dari pemerintah pusat dalam pencairan Danais. ${ }^{6}$

Proses penganggaran Danais DIY pada dasarnya masih minim melibatkan masyarakat di akar rumput menurut kajian Sakir dan Sarofah (2020). Hal tersebut disebabkan oleh kesenjangan informasi masyarakat di akar rumput untuk terlibat dalam proses kebijakan Danais DIY, meskipun pemda telah memiliki platform Jogja Plan untuk menerima masukan masyarakat melalui proposal. ${ }^{7}$ Yudhatama

$4 \quad$ Laksmi Nurita Tanjung, Dyah Mutiarin, and Eko Priyo Purnomo, "Monitoring Dan Evaluasi Pemanfaatan Dana Keistimewaan Daerah Istimewa Yogyakarta Tahun 2013-2017," Jurnal Agregasi 6, no. 1 (2018): 65 85.

5 Bismar Harris Satriawan, “Analisis Kebijakan Anggaran Dana Keistimewaan Dalam Mewujudkan Kesejahteraan Masyarakat Daerah Istimewa Yogyakarta 2013-2017" (Yogyakarta, 2017): 22-25.

6 Sukirno and Dwi Kuncahyo, "Penerapan Desentralisasi Asimetris Dalam Penyelenggaraan Urusan Keistimewaan Daerah Istimewa Yogyakarta Sebagai Basis Otonomi Bagi Terwujudnya Kesejahteraan Rakyat," Cakrawala Hukum IX, no. 1 (2015): 130-147.

7 Sakir and Riska Sarofah, "Accountability Model for Utilization of Privilege Funds Special Region of
(2017) menemukan masalah lain yang menyebabkan masyarakat memiliki kendala untuk terlibat dalam proses kebijakan Danais DIY. Berdasarkan pendalamannya pada pembahasan Danais tahun 2015 ditemukan bahwa komunikasi politik dalam kebijakan cenderung top down. Selain itu, warga yang diundang dalam proses kebijakan pun justru meyakini bahwa pembahasan Danais bukan urusan mereka dan percaya dengan kearifan Sultan HB X sebagai Gubernur DIY. ${ }^{8}$

DPRD DIY sebagai representasi masyarakat tidak dapat berbuat banyak untuk ikut terlibat dalam kebijakan Danais. Temuan Kariem dan Purwaningsih (2018) menunjukan pihak pemda justru menganggap lancang DPRD DIY yang ingin terlibat mengawasi penggunaan Danais. Akhirnya, pihak DPRD DIY hanya bisa memberikan harapan pada pemda untuk menggunakan Danais sebaik mungkin. ${ }^{9}$ DPRD DIY sendiri kurang memiliki informasi mengenai penganggaran Danais menurut temuan Saputra dan Madril (2019). DPRD DIY juga tidak berani menggunakan hak interplasi terkait kebijakan Danais. DPRD DIY hanya dapat memastikan Danais benar-benar digunakan untuk peningkatan kesejahteraan melalui pengawasan APBD. Namun, tetap saja DPRD DIY tidak dilibatkan dalam perencanaan Danais. ${ }^{10}$

Berbeda dengan kajian sebelumnya yang menggunakan perspektif institusional untuk memahami masalah kebijakan Danais DIY yang belum mampu mendorong

Yogyakarta 2013-2017," Jurnal Aristo (Social, Politic, Humaniora) 8, no. 2 (2020): 334-340.

8 Iranda Yudhatama, "Komunikasi Politik Dan Partisipasi Warga Dalam Arena Perencanaan Dan Penganggaran Dana Keistimewaan DIY,” Jurnal Ilmu Komunikasi 15, no. 3 (2017): 209-211.

9 Muhammad Qur'anul Kariem and Titin Purwaningsih, "Analisis Fungsi Pengawasan DPRD PROVINSI Daerah Istimewa Yogjakarta (DIY) Dalam Pelaksanaan Keistimewaan," Politika: Jurnal Ilmu Politik 9, no. 2 (2018): 65-75.

10 Yulianta Saputra and Oce Madril, "Pengawasan DPRD DIY Terhadap Pemerintah Daerah Dalam Penggunaan Dana Keistimewaan," Jurnal Widya Pranata Hukum 1, no. 2 (2019): 85-95. 
peningkatan kesejahteraan masyarakat. Penulis menggunakan pendekatan ekonomi politik berbasis analisis hegemoni Gramscian berusaha menunjukan kepentingan kelas sosial yang berkuasa untuk mendorong kemunculan UUK DIY lah yang menyebabkan masyarakat tidak mendapatkan manfaat secara langsung dari kebijakan Danais. Pertanyaan penelitian yang berusaha dijawab adalah "Bagaimana hegemoni penguasa lokal membuat masyarakat tidak mampu membangun konter kekuasaan dalam kebijakan Danais DIY?" Tujuan penulisan ini juga untuk me-reframing bahwa pada dasarnya dorongan kemunculan UUK DIY dan diikuti dengan kucuran Danais untuk membiayai urusan keistimewaan adalah bagian dari cara kelas penguasa untuk mempertahankan kepentingannya.

\section{Kerangka Teori}

Penulis menggunakan konsep hegemoni untuk memaparkan upaya dari penguasa lokal untuk mempertahankan kepentingan kelas sosialnya, sehingga membuat upaya masyarakat DIY dalam mengawal penggunaan Dana Keistimewaan tidak berjalan dengan baik. Gagasan mengenai hegemoni berangkat dari refleksi yang dilakukan oleh Gramsci sebagai alat analisis untuk menjelaskan proses kontestasi kekuasaan yang melibatkan mobilisasi pengetahuan, sumber daya ekonomi dan budaya. ${ }^{11}$ Kontestasi tersebut membantu mengambarkan cara struktur kekuasaan mempertahankan legitimasi atas kelas sosialnya. Gagasan Gramsci menempatkan peran pengetahuan dan pengalaman praktis dalam kehidupan sosial yang dipengaruhi oleh struktur kekuasaan sebagai bentuk nyata kontestasi kekuasaan. Gramsci memandang bahwa kesadaran kritis dilakukan melalui pendidikan alternatif untuk menghadapi kelas

11 Banu Witono et al., "Hegemony Construction Of Local Government Financial Accountability In Indonesia," International Journal Of Scientific $\mathbb{E}$ Technology Research 8, no. 12 (2019): 405-407. sosial yang berkuasa. Gramsci memakai istilah perang posisi untuk membangun pengetahuan tandingan, demi menghadapi penetrasi nilai yang dilakukan oleh kelas sosial yang berkuasa.

Kunci konsep hegemoni adalah proses kekuasaan yang menjadikan pengetahuan dan mobilisasi sumber daya sebagai legitimasi kelas sosial. Legitimasi kelas sosial tidak dapat dilepaskan dari kondisi hubungan negara, masyarakat politik, dan masyarakat sipil. Masyarakat sipil sendiri dilihat sebagai sekelompok orang yang melakukan penyebaran pengetahuan yang berbeda dari pesan negara beserta aparatnya. ${ }^{12}$ Masyarakat politik sendiri adalah lembaga yang memegang kekuasaan dan menjalankan perintah dari kelas sosial yang berkuasa. Masyarakat politik bukan untuk mengantikan pemaknaan negara, melainkan untuk menunjukan hubungan koersif antara pemerintah bersama dengan aparatnya.

Hegemoni menjadi instrumen dari kelas penguasa untuk mempertahankan kekuasaannya atas masyarakat sipil. Hegemoni terjadi melalui proses penetrasi pengetahuan dan keyakinan melalui pembiasaan maupun indoktrinasi, sehingga menjadi kesadaran kolektif. Pemenuhan akses ruang ekonomi dan politik untuk kelas proletar menjadi alasan mendasar negara membutuhkan basis supremasi kelas sosial. Negara bersama dengan masyarakat sipil adalah entitas yang interaktif. Negara membutuhkan konstruksi dan kontestasi atas klaim legitimasi. Masyarakat sipil berkepentingan untuk memastikan bahwa pengaturan sumber daya sesuai dengan kebutuhannya. Negara membutuhkan basis supremasi untuk memastikan bahwa keyakinan masyarakat sipil sesuai dengan yang diyakini kelas sosial berkuasa.

Gagasan tersebut mengaitkan negara dengan persoalan intelektualitas, kepemimpinan moral dan etis. Hal tersebut

12 Benedetto Fontana, "Political Space and Hegemonic Power in Gramsci," Journal of Power 3, no. 3 (2010): 343-351. 
membuat hubungan antara negara dengan masyarakat sipil terkait erat di Barat. Superstruktur masyarakat sipil dibayangkan seperti 'parit pertahanan.' Masyarakat sipil yang memiliki struktur kompleks dibayangkan akan menjadi 'parit pertahanan' yang siap menghadapi berbagai bentuk serangan.

Konsep Timur dan Barat terkait erat dengan gagasan Gramsci mengenai perang posisi dan perang manuver. Perang manuver adalah serangan langsung terhadap tatanan sosial-politik berupa penggulingan negara sesuatu yang terjadi di Timur, di mana negara sangat kuat dan masyarakat sipil lemah. ${ }^{13}$ Konteks historis di Barat menunjukan sulitnya terjadi perang manuver disebabkan adanya masyarakat sipil yang kuat. Perang posisi memainkan peranan penting di Barat dengan bentuk konflik multi dimensi meliputi aspek politik, ideologi, intelektualitas, dan lain-lain. Konflik tersebut sebenarnya adalah 'pertarungan budaya' dalam masyarakat sipil.

Masyarakat sipil menjadi arena berbagai konsepsi tentang dunia yang saling bertentangan satu sama lain dan bersaing untuk mendapatkan dukungan rakyat. Arena tersebut menjadi tempat terbentuknya konsensus dan dukungan populer dimobilisasi. Pertempuran budaya yang dimaksud oleh Gramsci menjadi bentuk instrumen mempertahankan legitimasi dan melestarikan kekuatan ideologis serta membentuk tatanan baru. Gramsci menyebut krisis legitimasi sebagai titik balik penting yang menandakan adanya kemungkinan transformasi masyarakat secara radikal. Hal tersebut menjadi penentu penting proses revolusi sosial.

Pengalaman hidup memainkan peran penting dalam membentuk gagasan politik Gramsci khususnya dalam merevisi MarxismeLeninisme dengan memberi konsep "hegemoni borjuis dalam masyarakat sipil." Negara menjadi wahana dari kelas borjuis

13 Fontana, Hlm. 343-351. untuk mendapatkan persetujuan aktif dari mereka yang memerintah. Gramsci melihat negara pada dasarnya memiliki fungsi edukatif dan formatif. ${ }^{14}$ Fungsi edukasi mengacu pada upaya mengubah keinginan individu-individu menjadi kebutuhan kolektif melalui persetujuan dan kolaborasi. Negara menginternalisasi nilai-nilai melalui hukum untuk memastikan rakyatnya menjalankan kebutuhan kolektifnya. Fungsi formatif mengacu pada upaya negara melembagakan sesuatu. Hukum menjadi jalan bagi negara untuk membatasi nilai-nilai yang diyakini dan dipraktikkan oleh rakyat. Kedua fungsi tersebut menjadi jalan bagi negara untuk melakukan penetrasi nilai, demi terfasilitasinya kepentingan borjuasi. ${ }^{15}$

Lebih jauh Yalvac \& Joseph dengan melihat konteks Turki pada tahun 2000an mengembangkan konsep hegemoni dari Gramsci dengan merumuskan gagasan kedalaman hegemoni, hegemoni parsial dan mengelaborasi revolusi pasif. Hegemoni mengacu pada cara kelas penguasa mampu mempertahankan pemerintahannya melalui program modernisasi dan reorganisasi sosial. Hegemoni bukan hanya mengenai pembentukan aliansi, melainkan juga penggunaan struktur untuk mempertahankan kekuasaannya. ${ }^{16}$ Revolusi pasif menjadi bentuk kesinambungan tren transformasi sosial meliputi seluruh kelompok-kelompok sosial yang ada.

Kedalaman hegemoni dapat dimaknai sebagai pergeseran prioritas dan strategi dari negara yang dihubungkan dengan berbagai proyek hegemonik. Proyek hegemonik mengacu pada mobilisasi dukungan di balik program pemerintahan yang menegaskan

14 Asli Daldal, "Power and Ideology in Michel Foucault and Antonio Gramsci: A Comparative Analysis," Review of History and Political Science 2, no. 2 (2014): 153-158.

15 Daldal, Hlm 153-158.

16 Faruk Yalvaç and Jonathan Joseph, "Understanding Populist Politics in Turkey: A Hegemonic Depth Approach," Review of International Studies, 2019, 10-15. 
kepentingan jangka panjang dari kelas penguasa. Hal tersebut terkait erat dengan gagasan selanjutnya, yakni hegemoni parsial yang menunjukan adanya wajah ganda dari proses penetrasi nilai. Hegemoni parsial menjadi bentuk dari upaya mobilisasi dukungan yang tidak sempurna, sehingga konsensus belum terbentuk dengan kuat.

Analisa kelas yang digunakan oleh Gramsci menitikberatkan pada pembacaan atas penetrasi nilai yang terjadi dari suprastruktur terhadap infrastruktur, di mana proses konsensus terbentuk di masyarakat sipil. Hegemoni dalam pemaknaan Gramsci tentu tepat untuk membaca interaksi aspek material dan institusi kekuasaan dalam menciptakan basis legitimasi. Hal tersebut menjadi alat baca penting yang dapat digunakan untuk mendalami hegemoni yang mendorong munculnya UUK di DIY, tetapi kemudian memangkas kemungkinan tumbuhnya pengawalandarimasyarakatdalampemanfaatan Dana Keistimewaan. Konsep hegemoni dari Gramsci membantu penulis dalam mendalami upaya kelas sosial yang berkuasa di DIY untuk menggerakkan suprastrukturnya untuk mendorong munculnya UUK dan mendapatkan manfaat darinya. Konsep hegemoni dari Gramsci membantu penulis untuk memaparkan bagaimana rakyat kecil di DIY sulit membangun konter kekuasaan dalam mengawal penggunaan Danais DIY pasca pelaksanaan UUK sejak tahun 2013.

\section{Metode Penelitian}

Kajian ini adalah penelitian kualitatif hegemoni kelas penguasa di DIY dalam penggunaan Danais. Pengumpulan data dilakukan melalui wawancara mendalam, FGD, metode dokumentasi dari laporan pemerintahan baik yang berupa perencanaan maupun evaluasi program serta audit kebijakan dan penelusuran sumber sekunder dari artikel jurnal dan pemberitaan media. Wawancara mendalam dan FGD dilakukan pada Februari-April 2021 menggunakan platform Zoom Meeting disebabkan situasi pandemi Covid-19 yang tidak memungkinkan bertemu narasumber secara tatap muka. Wawancara mendalam dan FGD dilakukan dengan melibatkan Sekber Keistimewaan DIY, empat komunitas pedagang dan PKL di Kawasan Malioboro, pegiat dan pemerintah desa serta aktivis Lembaga Bantuan Hukum Yogyakarta (LBH Yogyakarta) dan Social Movement Institute (SMI). Analisis data dilakukan sejak proses perencanaan sampai dengan proses penarikan kesimpulan.

\section{Keistimewaan DIY dalam Selubung Hegemoni Kekuasaan Lokal}

Bagian ini akan dibagi menjadi dua bagian yang memaparkan bekerjanya hegemoni kekuasaan lokal yang menyebabkan masyarakat khususnya dari kelas bawah sulit memantau penggunaan Danais DIY. Subbagian pertama memaparkan mengenai tumbuhnya dorongan dari elit lokal yang mengatasnamakan "gerakan warga" untuk mendorong munculnya RUUK DIY sejak 1998. Pemaparan tersebut menjadi penting untuk mendalami siasat dalam membangun "konsensus" dan kesadaran sebagian besar elit untuk mendukung langgengnya hegemoni penguasa lokal yang sudah ada. Subbagian kedua mendalami terkait pelanggengan kekuasaan lokal dalam memanfaatkan kucuran Danais dan menghambat tumbuhnya konter hegemoni dari rakyat kecil DIY yang ingin mendapatkan perbaikan kesejahteraan.

Dorongan Kemunculan UUK sebagai Bentuk Pelanggengan Hegemoni

PerspektifGramscianmembantukitauntuk memahami tumbuhnya kesadaran antara elit lokal dengan "elit warga" untuk membangun kesadaran memperjuangkan bahkan memperkuat kekuasaan lokal yang dianggap 
memberikan manfaat bagi masyarakat DIY. Pendekatan hegemoni Gramsci yang lepas dari ekonomisme marxisme klasik membantu kita melihat bagaimana kebudayaan, pengetahuan dan "ideologi" menjadi instrumen penting untuk mempertahankan kepentingan kelas penguasa. ${ }^{17} \mathrm{Hal}$ tersebut dapat kita lihat dengan keengganan "elit warga" DIY untuk melakukan perubahan struktural di tingkat lokal, kala dihadapkan pada perubahan politik nasional pada $1998 .^{18}$

Tahun 1998 menjadi titik penting terbentuknya blok historis, sebuah istilah yang oleh Gramsci digunakan untuk menyebut aliansi antara kelas bawah dengan kelas lain bersama penguasa untuk melakukan perubahan struktural. Sebaliknya, blok historis yang terbangun di DIY semenjak 1998 justru menjadi ajang pertautan antara "elit warga" dan penguasa lokal untuk mencegah terjadinya perubahan struktural. "Elit warga" yang terdiri atas jajaran pemerintah desa seperti lurah, kepala dukuh, kelompok seniman, akademisi, dan lain-lain dapat kita identifikasi sebagai intelektual tradisional yang berusaha mencegah terjadinya perubahan struktural di DIY.

Para intelektual organik sejak 1998 bergerak secara sporadis termasuk dengan menggerakkan massa untuk mendukung pemilihan gubernur DIY dan wagub melalui penetapan. Hal tersebut disebabkan regulasi yang ada dianggap tidak secara jelas mengatur tata cara pengisian jabatan. Aksi-aksi sporadis sangat banyak, salah satunya dilakukan oleh Ismaya sebuah organisasi perkumpulan Kepala Dukuh se-DIY. Adik mantan Presiden

17 William K. Carroll, "Restructuring Capital, Reorganizing Consent: Gramsci, Political Economy, and Canada," Canad. Rev. SOC. ES Anth. 27, no. 3 (1990): 393-395.

18 David Effendi, "Lokalisasi Demokrasi: Politik Identitas Dalam Gerakan Keistimewaan di Yogyakarta Pasca Orde Baru, 2003-2012" (Yogyakarta, 2018): 10-16, https:// www.researchgate.net/publication/322383766 Lokalisasi_Demokrasi_Politik_Identitas_dalam_ Gerakan_Keistimewaan_di_Yogyakarta_Pasca_Orde_ Baru_2003-2012.
Soeharto, Suwito menjadi penggerak penting aksi organisasi tersebut. Sejak tahun 2007, mereka bersatu dengan organ lain di bawah GRY, namun tidak bertahan lama disebabkan perbedaan kepentingan pada Pemilu Legislatif Tahun 2009. ${ }^{19}$

Pasang surut aksi yang disokong para intelektual tradisonal mengenai tata cara pengisian jabatan gubernur/wagub DIY sempat terjadi pada 1998-2010. Eskalasi aksi baru meningkat sejak tahun 2010-2012. Hal tersebut berawal dari pandangan Presiden Susilo Bambang Yudhoyono (SBY) yang menganggap bahwa sistem monarki tidak sesuai dengan konstitusi dan jati diri NKRI. ${ }^{20}$ Pandangan Presiden SBY memicu berbagai aksi-aksi sporadis masyarakat bahkan merubah dukungan elit politik di tingkat lokal dan pusat untuk mendukung Keistimewaan DIY. Blok historis dari kelas penguasa lokal justru semakin kuat dengan adanya pertautan dengan kelas atas di tingkat pusat.

Berbagai aksi yang disokong intelektual tradisional di DIY tidak terhubung satu sama lain. Mereka secara garis besar terdiri atas tiga kelompok. Pertama, kelompok Semar Sembogo yang berasal dari jejaring kepala dukuh. Kedua, kelompok yang terbentuk disebabkan adanya kesamaan pandangan seperti Sekber Keistimewaan, Gentaraja, Gerakan Rakyat Mataram, Gerakan Rakyat Yogyakarta. Ketiga, kelompok-kelompok komunitas kesenian, kebudayaan, tukang becak, dan lain-lain.

Blok historis kelas penguasa lokal yang menguat tidak dapat dilepaskan oleh kondisi suprastruktur dan infrastruktur yang ada di DIY. Kondisi suprastruktur di DIY yang menegaskan bahwa sumber daya pertanahan dianggap menjadi "milik" raja

19 Effendi.

20 Andy Ilman Hakim and Meidy Kosandi, "Political Opportunity, MobilizingStructure, and Framing Process in Social Movement to Demand Special Autonomy in Yogyakarta 2010-2012," in 2nd International Conference on Social and Political Development (ICOSOP 2017), 2017, 166-171. 
Tabel 1. Indeks Gini menurut Provinsi di Pulau Jawa tahun 2003-2012

\begin{tabular}{lllllllllll}
\hline Provinsi & 2003 & 2004 & 2005 & 2006 & 2007 & 2008 & 2009 & 2010 & 2011 & 2012 \\
\hline DKI Jakarta & 0,31 & 0,36 & 0,30 & 0,36 & 0,34 & 0,33 & 0,36 & 0,36 & 0,44 & 0,42 \\
Jawa Barat & - & - & 0,34 & - & 0,34 & 0,35 & 0,36 & 0,36 & 0,41 & 0,41 \\
Banten & - & - & 0,36 & - & 0,37 & 0,34 & 0,37 & 0,42 & 0,40 & 0,39 \\
Jawa Tengah & 0,25 & 0,25 & 0,31 & 0,27 & 0,33 & 0,31 & 0,32 & 0,34 & 0,38 & 0,38 \\
DI & & & & & & & & & & \\
Yogyakarta & 0,34 & 0,37 & 0,41 & 0,37 & 0,37 & 0,36 & 0,38 & 0,41 & 0,40 & 0,43 \\
Jawa Timur & - & - & 0,36 & - & 0,34 & 0,33 & 0,33 & 0,34 & 0,37 & 0,36 \\
\end{tabular}

Sumber: Badan Pusat Statistik.

menyebabkan rakyat maupun elit desa yang menggunakannya berada di bawah kendali institusi tradisional. Hal tersebut membawa konsekuensi pada adanya struktur mobilisasi baik secara material maupun budaya yang menyebabkan rakyat kecil tidak dapat berbuat banyak untuk lepas dari jerat kelas penguasa. Intelektual tradisional seperti kepala dukuh juga mendapatkan keuntungan dari penggunaan tanah milik Kasultanan/ Pakualaman sebagai sumber pendapatan bagi mereka dan desanya. ${ }^{21}$

Infrastruktur yang ada berupa ikatan patron-klien antara kelas penguasa lokal dengan rakyat kecil. Infrastruktur yang ada memungkinan intelektual tradisional di akar rumput untuk memobilisasi rakyat kecil untuk mendukung agenda Keistimewaan yang disokong oleh penguasa lokal. Rakyat kecil tidak dapat secara mandiri memutuskan aspirasinya atau bahkan membangun blok historisnya sendiri disebabkan kuatnya mobilisasi secara ekonomi dan budaya. Struktur mobilisasi yang ada bahkan mampu mendorong pembiayaan secara mandiri berbagai pertemuan untuk mendukung agenda munculnya RUUK. ${ }^{22}$ Intelektual tradisional juga sangat kuat memanfaatkan saluran-saluran kebudayaan sebagai pintu

21 Hakim and Kosandi, Hlm. 166-171.

22 Hakim and Kosandi, Hlm. 166-171. masuk penting untuk membangun kesadaran dan "konsensus" di hadapan rakyat kecil.

Kondisi rakyat kecil yang mau tidak mau harus mengikuti pandangan blok historis kelas penguasa jelas memprihatinkan. Apalagi intelektual tradisional di akar rumput yang seharusnya menyuarakan kepentingan rakyat kecil justru memperjuangkan sendiri kepentingan kelasnya. Hal tersebut cukup miris disebabkan kondisi rakyat kecil di DIY sendiri Pasca Orde Baru sangat mengkhawatirkan. Realitas tersebut misalnya dapat dilihat melalui indikator kesenjangan pendapatan. Kesenjangan pendapatan sendiri dapat dilihat dengan koefisien gini. Apabila kita lihat Tabel 1., tingkat kesenjangan pendapatan di DIY sejak tahun 2003-2012 selalu menempati kondisi paling timpang dibandingkan provinsi lain di Pulau Jawa. ${ }^{23}$

Upaya dari masyarakat sipil lain yang berupaya membangun agenda sendiri berupa pengisian jabatan gubernur/wagub DIY tidak mampu terwujudkan disebabkan berhadapan dengan suprastruktur yang kuat. Gerakan masyarakat sipil yang disokong oleh kelas penguasa lokal mampu lebih kuat disebabkan didukung oleh pemerintah daerah

23 Devi Norita Noviana, "Analisis Tingkat Pertumbuhan Ekonomi Dan Tingkat Ketimpangan Pendapatan Antar Kabupaten/Kota Di Provinsi Daerah Istimewa Yogyakarta Tahun 2003-2012" (Universitas Diponegoro, 2014): 5. 
dan kalangan akademisi kampus. DPRD DIY bersama beberapa akademisi sempat menawarkan draft RUUK dimulai pada 2002/2003. ${ }^{24}$

Dukungan kuat dari pemberitaan media lokal terhadap gerakan pro penetapan menjadi instrumen penting lain dalam menyebarkan kesadaran massa di DIY. Media lokal seperti Kedaulatan Rakyat yang memang memiliki ikatan dengan kelas penguasa lokal secara terang-terangan mendukung agenda penetapan. Berbeda dengan media nasional seperti Kompas yang memberitakan secara seimbang berbagai sudut pandang dalam RUUK DIY. Media lokal seperti Kedaulatan Rakyat gencar menyebarkan pandangan kelas penguasa lokal disebabkan keleluasaan untuk menyatakan dukungan terhadap Kasultanan dan Pakualaman dengan mengirim surat maupun opini kepada dewan redaksi..$^{25}$

Infrastruktur yang ada dimanfaatkan oleh kelas penguasa lokal untuk membangun kembali identitas sebagai "Kawula Mataram" melalui simbol, mitos, nilai, tradisi dan romantisasi sejarah untuk mendukung agenda Keistimewaan versi mereka. $^{26}$ Mobilisasi pengetahuan dan wacana dilakukan tidak hanya melalui media lokal, tetapi juga seni musik, media sosial dan tulisan blog. Mobilisasi budaya dilakukan untuk memastikan adanya konsensus warga DIY. Perbedaan pandangan masyarakat sipil lain terhadap pandangan mereka akan dilihat sebagai bentuk gangguan terhadap tradisi. ${ }^{27}$ Kasultanan dan Pakualaman sendiri sebenarnya lebih banyak bersikap "memantau situasi" sampai akhirnya

24 Bastian Widyatama, “Applying Kingdom's Multiple Streams Framework in the Establishment of Law No. 13 of 2012 Concerning the Privilege of Yogyakarta Special Region," Journal of Government and Civil Society 2, no. 1 (2018): 7-11.

25 Effendi, hlm. 10-16.

26 David Effendi, "Collective Identity and Protest Tactics in Yogyakarta Under The Post-Suharto Regime," Journal of Government and Politics 6, no. 2 (2015): 205 . 211.

27 Effendi, Hlm. 205-211. pemerintah pusat menetapkan UUK DIY pada tahun 2012. ${ }^{28}$

Gerakan masyarakat sipil yang memiliki pandangan sendiri mengenai Keistimewaan DIY tidak mampu mengimbangi kekuatan kelas penguasa lokal dan membangun blok historisnya sendiri. Mereka sendiri sebenarnya terdiri atas berbagai kelompok yang terpisah, sehingga jangankan untuk membangun kesadaran kelas bawah untuk membangun aliansi lintas kelas pun belum mampu. Mereka terdiri dari LSM seperi IRE, PaRWI, Yayasan Gilang Siti, Yayasan Ronggowarsito, Kompak, KMKY, Forum LSM dan Yayasan Tunas Bangsa. ${ }^{29}$

Beberapa kalangan akademisi seperti Ichlasul Amal, Heru Nugroho, Amien Rais, Alfian Dharmawan, Muchsan, Warsito Utomo, dan Tim JIP UGM. Kalangan parpol yakni Partai Demokrat dan lembaga yaitu Komisi Pemilihan Umum Daerah (KPUD). Bahkan, putra Pakualam VIII, Angling Kusumo juga ingin diadakan proses pemilihan disebabkan dirinya ingin mencalonkan diri sebagai wagub. ${ }^{30}$ Kalangan tersebut dapat kita sebut sebagai intelektual organik disebabkan peran mereka dalam membangun konter narasi terhadap pengetahuan yang mapan di DIY.

Upayakonterhegemoniyangterfragmentasi dari berbagai intelektual organik ditanggapi secara serius. Para intelektual tradisional yang merasa tradisi dan kebudayaannya terusik tidak segan untuk melakukan "intimidasi" terhadap pandangan yang berbeda. Misalnya tindakan demonstrasi perkumpulan Carik (Sekretaris Desa) pada 23 Desember 2010 di rumah Ichlasul Amal, di mana mereka meminta mantan rektor salah satu kampus tersebut untuk minta maaf atas pernyataannya

28 Widyatama, Hlm. 7-11.

29 David Effendi, "Local Politics and Local Identity: Resistance to 'Liberal Democracy' in Yogyakarta Special Regions Of Indonesia" (The University Of Hawai'i, 2012): 66-67.

30 Effendi, Hlm 66-67. 
yang menyamakan aksi massa pro penetapan sama dengan gerakan organisasi PKI (Partai Komunis Indonesia). ${ }^{31}$ Ichlasul Amal sendiri membuat pernyataan tersebut disebabkan khawatir dengan aksi massa kalangan pro penetapan justru cenderung memaksakan kehendak seperti yang dilakukan underbouw PKI dulu. ${ }^{32}$

Kasus lain menimpa George Junus Aditjondro (GJA), saat massa yang mengatasnamakan "Kawula Mataram" mendatangi kontrakannya pada 2 Desember 2011. Massa meminta GJA untuk meninggalkan DIY atas pernyataannya yang dianggap menghina Kraton. ${ }^{33}$ Sultan HB X sendiri pada 8 Februari 2012 baru menanggapi kejadian tersebut dan menganggap peristiwa yang terjadi tidak terkait dengan beliau. Sultan HB X menganggap masalahnya dengan GJA sebagai masalah pribadi dan menjelaskan bahwa warga tidak berhak mengusir George. ${ }^{34}$

Bagian ini telah menunjukan kuatnya hegemoni kelas penguasa di DIY yang membelenggu kemungkinan munculnya pengetahuan dan wacana yang berbeda dari rakyat kecil. Perang posisi yang dipakai oleh Gramsci untuk menjelaskan upaya membangun kesadaran baru melalui afiliasi kuat intelektual organik dan rakyat kecil tidak berjalan dengan baik. Penyebabnya ada dua hal, yakni tidak adanya pendidikan alternatif untuk membangun kesadaran kritis rakyat kecil di akar rumput dan kuatnya struktur mobilisasi kelas penguasa. Apa yang terjadi di DIY dalam upaya kelas penguasa untuk menyokong UUK versi mereka yang disahkan menunjukan kuatnya suprastruktur dalam membelenggu kesadaran warga.

31 "Ichlasul Amal Didemo Massa Propenetapan," tribunnews.com, 2010.

32 "Rumah Ichlasul Amal Didemo," viva.co.id, 2010.

33 "Forum Masyarakat Yogya 'Usir' George Aditjondro," detik.com, 2011.

34 "HB X: Warga Tak Berhak Usir George Aditjondro," viva. co.id, 2012.
Dana Keistimewaan dalam Cengkaraman Hegemoni

Pengesahan UUK 13/2012 yang mengatur lima urusan Keistimewaan DIY yang kemudian dibiayai melalui gelontoran Dana Keistimewaan sejak tahun 2013 justru tidak menghentikan upaya intelektual organik untuk membangun konter hegemoni. DIY memang sejak tahun 1998 memiliki karakter hegemoni yang merosot (decadent), yakni kondisi yang memungkinkan tumbuhnya perlawanan rakyat kecil dari bawah. Hal tersebut dapat terjadi kala suprastruktur mampu mencapai kebutuhan dan sasarannya, tetapi sebenarnya mentalitas massa tidak sungguh-sungguh selaras dengan pengetahuan kelas penguasa. ${ }^{35}$ Realitas tersebut misalnya dapat kita lihat dari perlawanan masyarakat petani di Kulonprogo yang menghadapi upaya penambangan pasir besi oleh kelompok bisnis milik Kasultanan dan Pakualaman menjelang pengesahan UUK. ${ }^{36}$ Rakyat kecil yang terdampak langsung oleh kepentingan kelas penguasa lokal mulai berani melakukan perlawanan untuk membela penghidupannya.

Apalagi Pemda DIY di dalam kegiatan Musrenbang menyediakan Forum Keistimewaan untuk memfasilitasi masukan dari warga dalam penggunaan Dana Keistimewaan. Masyarakat juga difasilitasi untuk mengajukan usulan melalui platform jogjaplan.com. Forum yang ada sebenarnya tidak lantas mewadahi aspirasi dari masyarakat disebabkan usulan akan dievaluasi sesuai dengan program dan sasaran prioritas dalam RPJMD (Rencana Pembangunan Jangka Menengah Daerah). RPJMD sendiri menjadi instrumen pengetahuan yang jitu untuk meminggirkan kepentingan warga. Hal tersebut disebabkan RPJMD adalah operasionalisasi dari janji politik Gubernur dan Wakil Gubernur DIY. ${ }^{37}$

35 Adam David Morton, "On Gramsci," Politics 19, no. 1 (1999): 1-8.

36 Effendi, 2012, Hlm. 123-125

37 Muhammad Haidar Ali, "Pengelolaan Dan Pertanggungjawaban Dana Keistimewaan Di Daerah Istimewa Yogyakarta Berdasarkan Undang-Undang 
Warga yang diundang dalam Forum Keistimewaan pada dasarnya sekadar untuk melegitimasi rancangan kebijakan yang sudah dirancang oleh jajaran pemda. Warga hanya mendapatkan sosialisasi rancangan yang sudah ada. Warga yang diundang pun adalah mereka yang terkait dengan jejaring blok historis kelas penguasa yang sebelumnya mendorong munculnya UUK. Warga dari kelompok tersebut tidak akan menuntut aspirasi apapun dalam Dana Keistimewaan disebabkan bagi mereka yang penting Sultan telah mendapatkan posisi yang jelas secara hukum. Mereka justru menganggap bahwa pembahasan Danais adalah urusan pemda DIY. ${ }^{38}$

Masyarakat desa sendiri dapat mengakses penggunaan Danais melaluipengajuan kegiatan kepada dinas terkait. Danais yang didapat kebanyakan berasal urusan kebudayaan. Masyarakat desa di Nglanggeran, Gunungkidul misalnya mengakses dana kegiatan melalui Dinas Pariwisata DIY terkait penyelenggaraan acara di destinasi wisata. Masyarakat desa juga dapat mengakses pemanfaatan Danais urusan kebudayaan kepada Dinas Kebudayaan DIY berupa fasilitas gamelan. Pegiat desa sendiri sebenarnya menyayangkan pemanfaatan Danais oleh masyarakat hanya terbatas pada event dan pembelian sarana fisik seperti gamelan.

“..... Terkait hadirnya pemanfaatan dana keistimewaan yang diberikan kepada masyarakat itu cenderung lebih ke halhal yang sifatnya event saja. Di mana masyarakat dari kelompok seni budaya yang sebelumnya tampil tanpa mendapat pembiayaan, setelah ada Danais justru mengkhawatirkan sebab semua diukur nominal uang dalam melestarikan budaya.....". 39

No. 13 Tahun 2012 Tentang Keistimewaan Daerah Istimewa Yogyakarta” (Universitas Islam Indonesia Yogyakarta, 2020): 71-148.

38 Yudhatama, 2017, hlm. 208-211.

39 Hasil Wawancara dengan Sugeng Handoko, Pegiat Desa Nglanggeran, Gunungkidul pada 12 April 2021.
Pemberian Danais kepada masyarakat yang berupa program event destinasi wisata dan fasilitas gamelan kenyataannya juga tidak lantas memberikan keleluasaan dari warga dalam memberikan masukan. Program yang ada sebenarnya sudah dirancang secara rigid oleh pemda DIY dan masyarakat hanya bisa menerima pelaksanaan programnya. Masyarakat mendapatkan "manfaat" dari pemanfaatan Danais langsung dalam bentuk event dan penyerahan gamelan secara langsung. Masyarakat harus melakukan kompromi sendiri, agar pemanfaatan Danais dapat dirasakan manfaatnya oleh tiap dusun. Masyarakat desa harus melakukan pertemuan sendiri untuk memodifikasi sendiri kegiatan lain yang harus didanai sendiri oleh warga.

"...... Kita punya pertemuan rutin
tiap malam Selasa Kliwon di dalam
kegiatan pengembangan pariwisata yang
digunakan untuk pelaporan, evaluasi dan
perencanaan. Dari hasil pertemuan warga
akan dibangun kesepakatan di desa untuk
disepakati bagaimana mengatur kegiatan
yang tidak didanai oleh Danais....". ${ }^{40}$

Pegiat desa lain juga memperkuat bahwa memang masyarakat di akar rumput tidak memiliki kuasa yang memadai untuk terlibat apalagi mengawasi proses kebijakan Danais. Masyarakat desa hanya bisa mengakses dalam bentuk program yang sudah jadi dari Dinas Kebudayaan DIY. Masyarakat desa mengakses program biasanya melalui Pokdarwis (Kelompok Sadar Wisata) yang telah terbentuk. Pemanfaatan Danais bagi masyarakat nampaknya lebih banyak bagi mereka yang telah mapan dalam pengembangan destinasi wisata. Masyarakat desa sendiri dapat memanfaatkan program Danais dari dinas terkait setelah mengajukan proposal.

“..... Hubungannya dengan Danais itu biasanya kalau ada program dari

40 Hasil Wawancara dengan Sugeng Handoko, Pegiat Desa Nglanggeran, Kabupaten Gunungkidul pada 12 April 2021. 
Disbud lebih mudah mengakses melalui Pokdarwis yang dikelola di bawah Bumi Panggung.......... Biasanya melalui pengajuan proposal ke dinas. Jadi kalau pemerintah desa mengelola Komunitas Pojok Budaya yang memang berbasis desa budaya.....". 41

Sekber Keistimewaan sebagai salah satu organisasi yang getol mendorong kemunculan UUK yang pro penetapan pun menjelaskan bahwa mereka tidak memiliki kuasa memadai untuk terlibat secara langsung dalam kebijakan Danais. Meskipun, Ketua Sekber Keistimewaan sendiri masih menjabat sebagai Sekretaris Jenderal PUTRI (Perhimpunan Usaha Taman Rekreasi Indonesia), di mana GKR Bendoro menjadi ketuanya. PUTRI sendiri belum mendapatkan akses program Danais. Sekber Keistimewaan tidak menginisasi munculnya sebuah project pariwisata besar yang akan dibiayai Danais. Tiap organisasi yang ada di dalam Sekber Keistimewaan cenderung mengakses program Danais melalui kelompok masing-masing.

“.... Sekber itu tidak secara langsung mengakses, karena program Danais sangat spesifik seperti desa budaya, desa wisata, dan sebagainya. Sekber itu personal ya misal dia menjadi penggerak. Kan ada ya teman-teman kita yang menjadi pendamping atau penggerak desa wisata dan budaya......"(Hasil wawancara dengan Ketua Sekber Keistimewaan pada 7 April 2021).

Sekber Keistimewaan sendiri sebagai organisasi masyarakat pendukung UUK menyayangkan penggunaan Danais yang terbatas untuk proyek-proyek fisik. Sekber Keistimewaan sendiri lebih menginginkan Danais lebih banyak untuk program pengembangan sumber daya manusia. Ketua Sekber Keistimewaan menganggap bahwa

41 Hasil Wawancara dengan Sekar, Pengurus BUMDES Desa Panggungharjo, Kabupaten Bantul pada 12 April 2021. penggunaan Danais sebatas untuk proyek fisik tidak dapat dilepaskan dari kepentingan Pemda DIY untuk memudahkan proses pelaporan dan mengejar target serapan anggaran.

“..... Betul, kita pengennya neraca itu lebih banyak ke pembangunan SDM, kita banyak mengkritik. Kita melihat kenapa neracanya lebih banyak ke belanja fisik mungkin kepentingan politik serapan anggaran ya. Karena kalau belanja fisik proyek tidak terlalu banyak, tetapi nilainya besar......." ${ }^{42}$

Sekber Keistimewaan menyampaikan kritik dengan memberikan masukan secara personal dengan pejabat daerah. Hal tersebut dapat disebabkan mereka tidak ingin sampai menyinggung secara keras blok historis kelas penguasa. Misalnya saat Ketua Sekber Keistimewaan menyampaikan kritik pembangunan toilet di depan Bank Indonesia cabang DIY yang menghabiskan dana empat milyar kepada Ketua Parampara Praja DIY saat itu, Mahfud MD. Ketua Sekber Keistimewaan mempertanyakan penggunaan Danais dalam jumlah besar sekadar untuk pembangunan toilet internasional di satu tempat. Ketua Sekber Keistimewaan juga mempertanyakan pembelian berbagai gedung yang perencanaannya tidak memadai sejak awal. Namun, tetap saja masukan-masukan secara personal tidak ditindaklanjuti oleh pihak Pemda DIY. ${ }^{43}$

Apabila kita cermati, pemanfaatan Danais oleh masyarakat memang lebih banyak dalam urusan kebudayaan. Hal tersebut tidak dapat dilepaskan sejak dikucurkan pada tahun 2013, urusan kebudayaan memang menjadi urusan keistimewaan yang memiliki porsi anggaran yang paling besar. Kucuran Danais untuk urusan kebudayaan pada tahun 2013-2018

\footnotetext{
42 Hasil wawancara dengan Ketua Sekber Keistimewaan pada 7 April 2021.

43 Hasil wawancara dengan Ketua Sekber Keistimewaan pada 7
} April 2021. 
Tabel 2. Dana Keistimewaan DIY 2013-2018

Penggunaan Dana Keistimewaan per Urusan

\begin{tabular}{llcccc}
\cline { 2 - 5 } Tahun & $\begin{array}{c}\text { Tata Cara } \\
\text { Pengisian Jabatan }\end{array}$ & Kelembagaan & Kebudayaan & Pertanahan & Tata Ruang \\
\hline 2013 & - & 2.516 .142 .500 & 212.546 .511 .000 & 6.300 .000 .000 & 10.030 .000 .000 \\
\hline 2014 & 400.000 .000 & 1.676 .000 .000 & 375.178 .719 .000 & 23.000 .000 .000 & 123.620 .000 .000 \\
\hline 2015 & - & 1.650 .000 .000 & 420.800 .000 .000 & 10.600 .000 .000 & 114.400 .000 .000 \\
\hline 2016 & - & 1.800 .000 .000 & 179.050 .365 .000 & 13.850 .000 .000 & 13.850 .000 .000 \\
\hline 2017 & 2.832 .737 .000 & 14.256 .040 .000 & 439.901 .748 .000 & 17.197 .300 .000 & 325.812 .175 .000 \\
\hline 2018 & - & 13.845 .000 .000 & 396.633 .000 .000 & 23.040 .388 .000 & 556.481 .612 .000 \\
\hline
\end{tabular}

Sumber: Diolah dari Bappeda DIY.

saja selalu mengalami peningkatan dan selalu memiliki porsi yang lebih besar dibandingkan urusan keistimewaan.

Laporan Keterangan Pertanggungjawaban (LKPJ) Gubernur Daerah Istimewa Yogyakarta Tahun 2016 sendiri memberikan catatan serius terhadap masalah pengawasan penggunaan Danais urusan kebudayaan oleh internal pemda DIY dan masyarakat. Masalah pelaksanaan hibah urusan kebudayaan sendiri terjadi pada tahun 2015 disebabkan Kuasa Pengguna Anggaran ragu-ragu dalam memahami ketentuan pada pasal 298 ayat (5) UU 23 Tahun 2014 tentang Pemerintahan Daerah yang mengatur syarat pemberian hibah kepada kelompok masyarakat yang harus berbadan hukum.

Akibat lemahnya pengawasan sendiri pada tahun 2015 terjadi masalah beberapa pekerjaan konstruksi seperi pembangunan anjungan TMII tidak mampu diselesaikan sesuai kontrak pengadaan barang dan jasa yang disepakati. Laporan Keterangan Pertanggungjawaban (LKPJ) Gubernur Daerah Istimewa Yogyakarta Tahun 2018 juga menunjukan bahwa terjadi masalah dalam pengawasan penggunaan Danais yang telah disepakati dengan kontraktor yakni dalam pengadaan seperangkat gamelan, gagal lelang renovasi cagar budaya dan transliterasi naskah kuno yang rusak.
Laporan Keterangan Pertanggungjawaban (LKPJ) Gubernur Daerah Istimewa Yogyakarta Tahun 2016 terkait penggunaan Danais dalam urusan pertanahan juga menunjukan masalah yang muncul akibat lemahnya pengawasan. Masalah yang muncul adalah perbedaan biaya pendaftaran 175 bidang tanah kasultanan dan kadipaten di BPN (Badan Pertanahan Nasional) dan perbedaan pengukuran tanah yang menggunakan satuan luasan bukan satuan bidang membuat perbedaan biaya pendaftaran. Laporan Keterangan Pertanggungjawaban (LKPJ) Gubernur Daerah Istimewa Yogyakarta Tahun 2018 menemukan terjadi masalah deviasi keuangan cukup serius disebabkan terjadi sisa lelang pengadaan patok batas tanah desa dan efisensii dari pelaksanaan kegiatan seperti sisa biaya untuk pendaftaran Tanah Kasultanan dan Kadipaten di BPN.

Sayangnya, proses pendaftaran tanah Kasultanan/Pakualaman sendiri tidak melibatkan warga terdampak yang justru memicu sengketa pertanahan. Hal tersebut misalnya terjadi dalam proses ganti rugi lahan terdampak proyek NYIA (New Yogyakarta International Airport), di mana terjadi perbedaan penafsiran atas bukti hak atas tanah antara Pakualaman dan warga. Pengageng Kawedanan Keprajan Kadipaten Pakualaman KPH Suryo Adi Negoro (Bayudana) mengklaim kepemilikan tanah Pakualaman seluas 160 
hektar didasarkan pada Rijksblad 1918. Tanah yang menjadi objek sengketa sendiri sudah mendapat ganti rugi sebesar Rp 701 miliar. Keluarga Pakubuwono X turut pula memiliki klaim atas tanah yang menjadi objek sengketa dengan berdasar pada sertifikat Eigendom Verponding atau bukti kepemilikan tanah masa Hindia Belanda. ${ }^{44}$

Laporan Keterangan Pertanggungjawaban (LKPJ) Gubernur Daerah Istimewa Yogyakarta Tahun 2016 juga menunjukan adanya permasalahan dalam urusan tata ruang. Tahun 2015 beberapa kegiatan tidak dapat dilaksanakan disebabkan adanya gagal lelang pengadaan tanah untuk penataan kendaraan tidak bermotor di Kawasan Budaya Perkotaan Yogyakarta dan efisiensi pelaksanaan kegiatan terutama OPD Dinas Perhubungan Kota Yogyakarta. LKPJ Gubernur DIY Tahun 2018 juga menunjukan adanya masalah pengadaan barang dan jasa dalam urusan tata ruang disebabkan warga tidak bersediia menerima pembebasan lahan untuk proyek Kawasan Lava Bantal.

Pengawasan Danais di dalam internal pemerintahan daerah DIY sendiri melibatkan inspektorat, Bappeda, dan DPRD DIY. Inspektorat mengawasi mulai dari perencanaan program s.d. evaluasi program yang terkait dengan urusan Keistimewaan. Bappeda melaksanakan pengawasan penggunaan Danais tiap tiga bulan sekali. DPRD DIY hanya berhak mengawasi dalam proses pembahasan dan penyusunan Perdais. RPJMD dan RKPD. Meskipun, melewati pengawasan internal pemerintahan daerah tetap saja nyatanya penggunaan Danais tidak lepas dari masalah perbedaan pandangan masing-masing Organisasi Perangkat Daerah (OPD) dan tidak adanya alat ukur outcome program/kegiatan keistimewaan. ${ }^{45}$

44 tirto.id, "Untung Pakualaman Di Tengah Nasib Buntung Petani Dari Proyek NYIA,” tirto.id, 2018.

Ali, 2020, hlm. 71-148.
DPRD DIY sendiri tidak dapat mengawasi Danais secara ketat juga karena pertanggungjawaban anggaran langsung diberikan ke Pusat. DPRD DIY sendiri dalam posisi yang sulit disebabkan mau tidak mau mengesahkan Danais yang melekat di APBD. Pengawasan oleh pemerintah pusat juga belum memadai untuk mencegah Danais hanya menguntungkan kepentingan kelas penguasa lokal. Pemeriksaan oleh BPK RI terbatas pada penggunaan dana rutin. Kehadiran BPKP sebatas pemberian bimbingan dan koordinasi teknis. Sementara itu, kalangan akademisi dan LSM tidak cukup kuat untuk membangun konter hegemoni menghadapi penguasa lokal. ${ }^{46}$

Pegiat SMI memaparkan bahwa sejak tekanan massa kepada GJA terjadi pada akhir tahun 2011, kalangan LSM dan akademisi di DIY mulai menghindari perbincangan dan advokasi yang berkaitan dengan kekuasaan lokal. Bahkan, kala para aktivis dan pegiat gerakan sosial mendapatkan represi baik dari kalangan aparat maupun kelompok masyarakat tertentu sulit sekali membangun solidaritas di antara anggota LSM dan akademisi kampus. Kalangan aktivis harus berusaha mencari perlindungan dari LSM-nya sendiri, apabila menjadi sasaran tindakan represif.

“........Kita benar-benar sangat membatasi apalagi isu yang menyangkut sultan, itu sejak peristiwa George Aditjondro yang diserbu menjadi traumatik sekali. Tekanannya luar biasa apalagi isu seputar kerajaan itu benar-benar isu yang bisa berujung menjadi korban persekusi......" ${ }^{47}$

Beberapa kalangan LSM seperti Perkumpulan IDEA, LBH Yogyakarta, PUKAT UGM, Indonesia Court Monitoring, dan masih banyak lagi bersama kawan-kawan

\footnotetext{
46 Nyimas Latifah Letty Aziz et al., "Pengawasan Dana Otonomi Khusus Dan Istimewa : Problematika Dan Solusi" (Jakarta, 2016). 47 Hasil wawancara dengan pegiat SMI pada 31 Maret
} 2021 
jurnalis sempat membuat kolaborasi bersama dalam pengawasan penggunaan Danais untuk proyek penataan pedagang kaki lima (PKL) di Kawasan Malioboro. Upaya mereka menemukan adanya kejanggalan dalam proyek penataan PKL ke gedung bekas Bioskop Indra. Kolaborasi antara jurnalis dan LSM tersebut menemukan risiko tingkat korupsi tinggi pada proyek yang didanai Danais tersebut. Ada dua indikator yang digunakan oleh koalisi masyarakat sipil untuk menilai risiko dari proyek penataan di Bioskop Indra yakni, nilai kontrak yang tinggi dan rendahnya partisipasi peserta tender yang terlibat dalam tahap I pembangunan. ${ }^{48}$

Ada beberapa dugaan pelanggaran yang ada dalam proyek yang didanai oleh danais tersebut. Pertama, dugaan pelanggaran Perpres 4 Tahun 2015 tentang Perubahan Keempat Atas Peraturan Presiden Nomor 54 Tahun 2010 Tentang Pengadaan Barang/Jasa Pemerintah khususnya terkait lelang tahap I dalam pembangunan eks bioskop Indra dengan memilih lokasi relokasi yang tidak sederhana. Kedua, dugaan persengkongkolan dan persaingan tidak sehat dalam tender tahap II dan III yang memenangkan dua perusahaan berbeda dengan pemilik yang sama yang melanggar ketentuan UU No 20 tahun 2008. Ketiga, dugaan pelanggaran hukum oleh pemda DIY sebagai akibat membangun proyek relokasi di atas tanah sengketa dan kesalahan pemberian talih asih dengan biaya sebesar Rp 18.000.000.000 pada orang yang tinggal menumpang di lahan tersebut. ${ }^{49}$

48 perkumpulanidea.or.id, "Monitoring Pengadaan Barang/Jasa Di Pemerintah DIY," perkumpulanidea. or.id,2020,http://perkumpulanidea.or.id/ monitoring-pengadaan-barang-jasa-di-pemerintah-di y/?fbclid=IwAR0J2BK4rRhNbAvyMzq2n6oReklFPKHQpcvVsrMGewjlO4lqJM9HNbDyDA.

49 perkumpulanidea.or.id.
Tabel 3. Alokasi Dana Keistimewaan dalam Proyek Penataan Bekas Gedung Bioskop Indra

\begin{tabular}{ll}
$\begin{array}{c}\text { Tahapan } \\
\text { Pembangunan }\end{array}$ & \multicolumn{1}{c}{$\begin{array}{c}\text { Besaran Pembiayaan dari } \\
\text { Danais }\end{array}$} \\
\hline Tahap 1 2018 & Rp 44.100.000.000,00 \\
\hline Tahap 2 2018 & Rp 15.100.000.000,00 \\
\hline Tahap 3 2019 & Rp 3.000.000.000,00 \\
\hline Jumlah & Rp 62.200.000.000,00 \\
\hline Sumber: Perkumpulan IDEA
\end{tabular}

Upaya kolaborasi LSM dan jurnalis untuk mendapatkan dokumen lelang proyek Bioskop Indra tidak mudah. Mereka memulai dengan menemui pejabat Unit Layanan Pengadaan (ULP) dan Dinas Pekerjaan Umum Perumahan dan Energi Sumber Daya Mineral (PUP-ESDM), namun tidak berhasil mendapatkan dokumen lelang. Kepala Dinas PUP-ESDM enggan memberikan dokumen dengan alasan bukan terbuka untuk publik dengan mengacu pada Keputusan Menteri Pekerjaan Umum Nomor 451 Tahun 2017 tentang Daftar Informasi yang Dikecualikan. Setelah dilakukan pengecekan ternyata keputusan menteri tersebut hanya mengatur pada level pusat bukan daerah. Pegiat Perkumpulan IDEA kembali menemui kepala dinas dengan seperangkat dokumen regulasi yang menjelaskan bahwa dokumen lelang adalah bagian dari informasi publik. ${ }^{50}$

Perkumpulan IDEA sempat bersurat dua kali, tetapi baru direspon setelah mengajukan surat keberatan. Kepala Biro Pengembangan Infrastruktur Wilayah kemudian meminta adanya mediasi dengan Perkumpulan IDEA. Setelah dilakukan pertemuan antara pegiat Perkumpulan IDEA dengan Asisten Perekonomian dan Pembangunan Sekretariat Daerah Provinsi Yogyakarta dan Kepala Biro Pengembangan Infrastruktur Wilayah ternyata mediasi yang dimaksud adalah permintaan untuk "tidak memaksa" meminta dokumen lelang. Akhirnya para pejabat mau

50 perkumpulanidea.or.id, "Lobi-Lobi Merebut Dokumen Anggaran Relokasi,” perkumpulanidea.or.id, 2021. 


\section{Jalan Panjang Memperoleh Dokumen Anggaran}

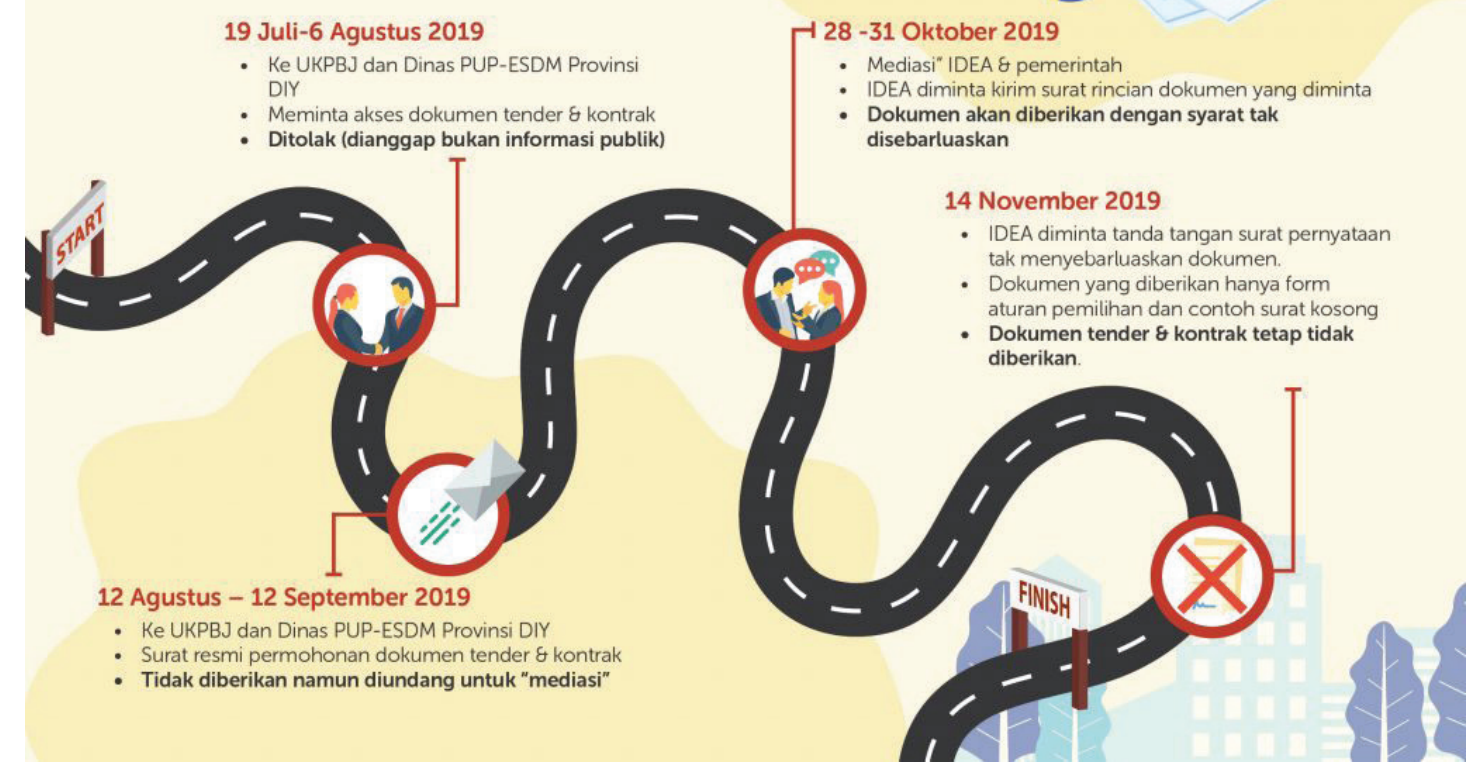

Gambar 1. Proses Panjang Pengawalan Sengkarut Proyek Penataan PKL Malioboro Sumber: Perkumpulan IDEA

menyerahkan dokumen dengan syarat tidak disebarkan ke publik. Setelah diberikan ternyata yang didapatkan kolaborasi LSM dan jurnalis bukan dokumen lelang, melainkan hanya rangkuman proses lelang dan regulasi terkait proses penawaran.

Realitas yang terjadi di DIY menunjukan bahwa rakyat kecil di akar rumput tidak mampu membangun aliansi lintas kelas bersama dengan para intelektual organik. Para intelektual organik sendiri terkesan bergerak sendiri dengan mengandalkan kekuatan yang ada di dalam kelas sosialnya tanpa membangun kesadaran kritis bagi rakyat kecil di akar rumput, meskipun sudah berusaha meraih atensi publik dalam pengawalan Danais DIY. Namun, upaya memberitakan hasil investigasi belum cukup disebabkan untuk menghadapi hegemoni kelas penguasa perlu menandingi mobilisasi budaya, ideologi dan wacana pengetahuan yang disampaikan sampai dengan tingkat elit di akar rumput. ${ }^{51}$

51 Ercan Gündolan, "Conceptions of Hegemony in Antonio Gramsci's Southern Question and the Prison
Proses pemberitaan belum dapat dikatakan sebagai upaya membangun kesadaran kritis disebabkan tidak diikuti oleh proses pendidikan alternatif bagi massa. Akibatnya, tentu saja di antara sesama warga di akar rumput belum terdapat kesepahaman bersama mengenai pentingnya pengawalan Danais bagi peningkatan kesejahteraan mereka.

Tidak adanya pendidikan alternatif untuk membangun kesadaran kritis masyarakat justru menyebabkan rakyat kecil di DIY mewajarkan kondisi kemiskinan. Jangankan untuk menyadari pentingnya mengawal penggunaan Danais bagi peningkatan kesejahteraan, rakyat kecil DIY cenderung pasrah atas kondisi kemiskinan yang mereka hadapi. Studi yang dilakukan LIPI pada tahun 2015-2017 bahkan menunjukan sikap kepasrahan rakyat kecil terhadap kondisi ketimpangan menyebabkan program pengentasan kemiskinan tidak berjalan dengan baik. Rakyat kecil masih menganggap bahwa kemiskinan yang mereka

Notebooks," New Proposals: Journal of Marxism and Interdisciplinary Inquiry 2, no. 1 (2008): 47-50. 
derita adalah takdir Tuhan yang tidak dapat ditolak. Rakyat kecil di DIY percaya bahwa mereka masih dapat memenuhi penghidupan dengan bantuan dari lingkungan sosialnya. ${ }^{52}$

Penerimaan rakyat kecil terhadap kemiskinan mereka dalam kacamata Gramsci dapat dijelaskan sebagai bagian dari mobilisasi pengetahuan dan moralitas yang dilakukan oleh kelas penguasa untuk mempertahankan basis sosial. ${ }^{53}$ Apalagi Sultan HB X pernah menjelaskan bahwa parameter yang dipakai untuk melihat kemiskinan di DIY belum memadai disebabkan tidak mengukur tabungan hewan ternak milik warga miskin. Menurut Sultan HB X, rakyat kecil memilih nrimo asalkan hewan ternaknya tetap sehat..$^{54}$ Hal tersebut sebenarnya adalah bentuk naluri kelas dari rakyat kecil untuk menormalkan keadaan disebabkan ketidakmampuan mereka dalam membangun perjuangan kelas. Posisi rakyat kecil yang lemah di antara masyarakat sipil lain membuat mereka pasif dalam aktivitas politik. Dengan demikian, seolah-olah keadaan penghidupan tiap kelas sosial terlihat "normal" akibat tidak adanya kesadaran dari kelas bawah untuk mempertanyakan kemiskinan yang mereka hadapi. ${ }^{55}$

Basis sosial dari hegemoni kelas penguasa masih belum mampu ditandingi oleh intelektual organik yang belum memiliki ikatan kuat dengan massa. Aliansi lintas kelas menjadi sulit muncul untuk bersamasama mengawal penggunaan Danais di DIY. Gramsci menjelaskan bahwa semestinya proses konter hegemoni terhadap kelas penguasa

52 Aulia Hadi, "Pola Kerentanan Masyarakat Miskin Perdesaan Dan Perkotaan Terhadap Keberlangsungan Hidupnya," in Tinjauan Kritis Ketahanan Masyarakat Miskin Perkotaan Dan Perdesaan: Ruang Sosial, Kebijakan Dan Pola Kerentanan Sosial, ed. Thung Ju Lan (Jakarta: LIPI Press, 2019), 143-233.

53 Arun Patnaik, "The Contemporary Significance of Gramsci's Critique of Civil Society," WorkingUSA: The Journal of Labor and Society 15 (2012): 580-583.

54 kumparan.com, "Sultan HB X: Banyak Warga Miskin Punya Tabungan Hewan Ternak," kumparan.com, 2019.

55 Patnaik, 2012, Hlm. 580-583. diarahkan oleh massa kelas bawah bukannya disetir oleh intelektual organik. Upaya perang posisi harus digerakkan oleh massa lintas kelas yang digerakkan oleh kesadaran kritis yang dibangun melalui pendidikan alternatif. ${ }^{56}$

Tanpa adanya aliansi lintas kelas, massa tidak akan mampu menembus korporatisme. Korporatisme menjadi bentuk instrumen kelas penguasa dengan menjadikan negara mengamankan kepentingan kapitalnya. Hal tersebut terlihat dalam realitas betapa sulitnya rakyat mendapatkan informasi mengenai kebijakan Danais di DIY. Bentuk lain dari korporatisme tersebut dapat juga dilakukan dalam bentuk kelas penguasa menggerakkan organ pendukungnya untuk memonopoli proses kebijakan misalnya terlihat dalam pembuatan program Jaga Warga.

Jaga Warga sendiri muncul dari ide Sultan HB X yang resah dengan masalah kesenjangan sosial di DIY serta untuk penanggulangan terorisme. Sultan HB X mengusulkan pembentukan Jaga Warga yang operasionalnya akan dibiayai oleh Danais sampai tingkat pedukuhan. Jaga Warga sendiri menjadi cara praktis yang diusulkan Gubernur DIY untuk mengatasi masalah kesenjangan dengan pendekatan keamanan. Fungsinya menjadi lebih banyak untuk mengatasi gejolak yang ditimbulkan oleh masalah kesenjangan sosial di DIY.

Pegiat SMI yang pernah terlibat dalam perumusan sendiri memilih keluar dari proses pembahasan program Jaga Warga yang dianggap memfasilitasi tumbuhnya kekuatan paramiliter di akar rumput. Hal tersebut disebabkan pendekatan yang dipakai adalah lebih banyak kegiatan razia dan pengamanan di tingkat pedukuhan, apalagi menjadi semakin gencar dilakukan kala pandemi Covid-19 terjadi.

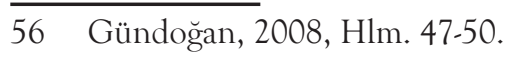


"....... Saya keluar dari mekanisme itu karena ini seperti vigilante yang direstui di tingkat lokal karena tiap pedukuhan dan itu di bawah Satpol PP, maka itu organisasi itu benar-benar terbentuk vigilante resmi....". 57

Pegiat SMI juga menjelaskan bahwa selama membantu dalam perancangan program, pihak kepolisian pasti akan mengajak paramiliter yang dekat dengan penguasa lokal seperti Pemuda Pancasila dan Paksi Katon. Menurut pegiat SMI, apabila diliat pada daftar hadir pembahasan program, maka organisasi masyarakat sipil yang hadir adalah Pemuda Pancasila, Paksi Katon dan FKUB. Bahkan berbagai kelompok paramiliter tersebut dilibatkan dalam program Danais yang tidak terkait dengan sektor keamanan seperti pemberdayaan ekonomi.

“...... Apa kaitannya Pemuda Pancasila dengan penguatan ekonomi, tapi dari program itu mereka punya program misalnya mereka punya program penguatan nelayan di Parangtritis. Ini tidak ada programnya, mereka hanya mengada-ada karena ada program baru....." ${ }^{58}$

Pegiat SMI memaparkan terdapat satu lagi pihak yang dekat dengan penguasa lokal yang selalu diundang dalam berbagai forum program dari Danais, yakni takmir masjid J. Takmir masjid J diwakili oleh Ustaz J seringkali diundang di hampir semua isu baik penggunaan Danais s.d. anti komunisme. Menurut pegiat SMI, Ustaz J bahkan lebih sering diundang oleh pihak Pemda DIY dibandingkan dengan ketua FPI DIY. Ustaz J memang memiliki jejaring sosial-politik yang kuat di DIY disebabkan pernah menjabat fungsionaris PKS (Partai Keadilan Sejahtera) dan sampai sekarang masih membangun koneksi dengan partai tersebut. Ustaz J juga

57 Hasil wawancara dengan pegiat SMI pada 31 Maret 2021.

58 Hasil Wawancara dengan Pegiat SMI pada 31 Maret 2021. memiliki koneksi dengan banyak akademisi dan pengusaha, sehingga memiliki pengaruh sosial-politik yang kuat di DIY. ${ }^{59}$

Hegemoni yang merosot di DIY yang terjadi akibat adanya upaya dari intelektual organik untuk mengawal kebijakan Danais nampaknya belum mampu mendorong munculnya aliansi lintas kelas. Kuatnya kelas penguasa dalam memobilisasi intelektual tradisional dan struktur pemerintahan masih belum dapat ditembus oleh intelektual organik yang belum mampu membangun kesadaran kritis di akar rumput. Perang posisi belum terjadi atau dapat dikatan terjadi di segelintir kalangan intelektual organik. ${ }^{60}$ Kondisi pelanggengan hegemoni sejak pengusulan UUK sampai dengan pelaksanaannya pasca tahun 2013 telah membelenggu kemungkinan munculnya konter hegemoni.

\section{Kesimpulan}

Tulisan ini telah menunjukan betapa sulitnya kelas bawah dan intelektual organik di DIY dalam membangun kekuatan politik tandingan dalam mengawal kebijakan Danais. Kekuasaan hegemonik dari kelas penguasa lokal yang didukung oleh kuasa media massa, budaya, dan para intelektual tradisional yang sudah mendukung sejak pengusulan RUUK menyebabkan kebijakan Danais dimonopoli oleh penguasa lokal. Kanal-kanal partisipasi yang telah disediakan tidak lantas mampu memberikan ruang bagi rakyat kecil untuk mengontrol kebijakan Danais juga disebabkan oleh pengetahuan mereka yang mewajarkan ketimpangan. Upaya dari intelektual organik sayangnya tidak diikuti dengan pendidikan massa menyebabkan mereka terkesan bergerak sendiri dalam mengawal kebijakan Danais DIY.

59 Ahmad M. Arrozy, "Perubahan Sosial Komunitas Masjid Kampung Jogokariyan Yogyakarta Tinjauan SosiologiSejarah,” Jurnal Analisa Sosiologi April 5, no. 1 (2016): 109.

60 Lilian Miles and Richard Croucher, "Gramsci, Counter-Hegemony and Labour Union-Civil Society Organisation Coalitions in Malaysia," Journal of Contemporary Asia, 2013, 3-6. 
Pendidikan alternatif bagi masyarakat diperlukan sebagai tindak lanjut kebijakan untuk menyiapkan warga terlibat dan mengawal penggunaan Danais, agar dapat dimanfaatkan untuk peningkatan kesejahteraan mereka. Pendidikan alternatif berbentuk riset aksi partisipatif menjadi kunci penting untuk mentautkan intelektual organik bersama dengan masyarakat dalam mengidentifikasi masalah dan sumber daya yang mereka miliki. Riset aksi partisipatif dapat membangun kesadaran kritis dan pemahaman bersama di akar rumput dalam mendorong atensi masyarakat untuk membangun aliansi gerakan. Aliansi gerakan menjadi blok historis penting untuk menandingi kekuatan dan basis sosial dari hegemoni kelas penguasa lokal di DIY.

\section{DAFTAR PUSTAKA}

Ali, Muhammad Haidar. "Pengelolaan Dan Pertanggungjawaban Dana Keistimewaan Di Daerah Istimewa Yogyakarta Berdasarkan Undangundang No. 13 Tahun 2012 Tentang Keistimewaan Daerah Istimewa Yogyakarta." Universitas Islam Indonesia Yogyakarta, 2020.

Arrozy, Ahmad M. "Perubahan Sosial Komunitas Masjid Kampung Jogokariyan Yogyakarta Tinjauan Sosiologi-Sejarah." Jurnal Analisa Sosiologi April 5, no. 1 (2016): 92-112.

Arum, Halimatus Fadilah Sekar, and Sakir Ridho Wijaya. "Pengaruh Dana Keistimewaan Yogyakarta Terhadap Kesejahteraan Masyarakat Di Kabupaten Bantul.” Jurnal Politikom Indonesiana: Kajian Ilmu Pemerintahan, Ilmu Politik Dan Ilmu Komunikasi 6, no. 1 (2021): 62-82.

Aziz, Nyimas Latifah Letty, R. Siti Zuhro, Heru Cahyono, Dini Suryani, Dian Aulia, and Yusuf Maulana. "Pengawasan Dana Otonomi Khusus Dan Istimewa : Problematika Dan Solusi.” Jakarta, 2016.
Carroll, William K. "Restructuring Capital, Reorganizing Consent: Gramsci, Political Economy, and Canada." Canad. Rev. SOC. Ë Anth. 27, no. 3 (1990): 390-416.

Daldal, Asli. "Power and Ideology in Michel Foucault and Antonio Gramsci: A Comparative Analysis." Review of History and Political Science 2, no. 2 (2014): 149-67.

detik.com. "Forum Masyarakat Yogya 'Usir' George Aditjondro." detik.com, 2011.

Effendi, David. "Collective Identity and Protest Tactics in Yogyakarta Under The PostSuharto Regime." Journal of Government and Politics 6, no. 2 (2015): 203-13.

-. "Local Politics and Local Identity: Resistance to 'Liberal Democracy' in Yogyakarta Special Regions Of Indonesia." The University Of Hawai'i, 2012.

—. "Lokalisasi Demokrasi: Politik Identitas Dalam Gerakan Keistimewaan Di Yogyakarta Pasca Orde Baru, 2003-2012.” Yogyakarta, 2018. https://www.researchgate.net/ publication/322383766_Lokalisasi_ Demokrasi_Politik_Identitas_dalam Gerakan_Keistimewaan_di_Yogyakarta_ Pasca_Orde_Baru_2003-2012.

Effendi, David, Rifki Sanahdi, and Agus Andika Putra. "Big Budget, Low Impact: An Alternative Evaluation On Benefit And Impact Of Special Fund In Di Yogyakarta, 2013-2015." Journal of Government and Politics International Conference II, no. X (2017): 263-75.

Fontana, Benedetto. "Political Space and Hegemonic Power in Gramsci." Journal of Power 3, no. 3 (2010): 341-63.

Gündoğan, Ercan. "Conceptions of Hegemony in Antonio Gramsci's Southern Question and the Prison Notebooks." New Proposals: Journal of Marxism and Interdisciplinary Inquiry 2, no. 1 (2008): 45-60. 
Hadi, Aulia. "Pola Kerentanan Masyarakat Miskin Perdesaan Dan Perkotaan Terhadap Keberlangsungan Hidupnya." In Tinjauan Kritis Ketahanan Masyarakat Miskin Perkotaan Dan Perdesaan: Ruang Sosial, Kebijakan Dan Pola Kerentanan Sosial, edited by Thung Ju Lan, 143-233. Jakarta: LIPI Press, 2019.

Hakim, Andy Ilman, and Meidy Kosandi. "Political Opportunity, Mobilizing Structure, and Framing Process in Social Movement to Demand Special Autonomy in Yogyakarta 2010-2012." In 2nd International Conference on Social and Political Development (ICOSOP 2017), 163-73, 2017.

Kariem, Muhammad Qur'anul, and Titin Purwaningsih. "ANALISIS FUNGSI PENGAWASAN DPRD PROVINSI DAERAH ISTIMEWA YOGJAKARTA (DIY) DALAM PELAKSANAAN KEISTIMEWAAN." Politika: Jurnal Ilmu Politik 9, no. 2 (2018): 61-81.

kumparan.com. "Sultan HB X: Banyak Warga Miskin Punya Tabungan Hewan Ternak." kumparan.com, 2019.

Miles, Lilian, and Richard Croucher. "Gramsci, Counter-Hegemony and Labour UnionCivil Society Organisation Coalitions in Malaysia." Journal of Contemporary Asia, 2013, 1-15.

Morton, Adam David. "On Gramsci." Politics 19, no. 1 (1999): 1-8.

Noviana, Devi Norita. "Analisis Tingkat Pertumbuhan Ekonomi Dan Tingkat Ketimpangan Pendapatan Antar Kabupaten/Kota Di Provinsi Daerah Istimewa Yogyakarta Tahun 2003-2012." Universitas Diponegoro, 2014.

Patnaik, Arun. "The Contemporary Significance of Gramsci's Critique of Civil Society." WorkingUSA: The Journal of Labor and Society 15 (2012): 577-588. perkumpulanidea.or.id. "Lobi-Lobi Merebut Dokumen Anggaran Relokasi." perkumpulanidea.or.id, 2021.

_. "Monitoring Pengadaan Barang/Jasa Di Pemerintah DIY." perkumpulanidea. or.id, 2020. http://perkumpulanidea. or.id/monitoring-pengadaan-barangjasa-di-pemerintah-diy/?fbclid $=$ IwAR OJ2BK4rRhNbAvyMzq2n6oRek1F. PKHQpcvVsrMGewjlO4lqJM9HNbDyDA.

Sakir, and Dyah Mutiarin. "Kebijakan Anggaran Dana Keistimewaan Daerah Istimewa Yogyakarta." Jurnal Ilmu Pemerintahan $\mathcal{E}$ Kebijakan Publik 2, no. 3 (2015): 462-92.

Sakir, and Riska Sarofah. "Accountability Model for Utilization of Privilege Funds Special Region of Yogyakarta 2013-2017.” Jurnal Aristo (Social, Politic, Humaniora) 8, no. 2 (2020): 328-42.

Saputra, Yulianta, and Oce Madril. "Pengawasan DPRD DIY Terhadap Pemerintah Daerah Dalam Penggunaan Dana Keistimewaan." Jurnal Widya Pranata Hukum 1, no. 2 (2019): 86-107.

Satriawan, Bismar Harris. "Analisis Kebijakan Anggaran Dana Keistimewaan Dalam Mewujudkan Kesejahteraan Masyarakat Daerah Istimewa Yogyakarta 2013-2017." Yogyakarta, 2017.

Sukirno, and Dwi Kuncahyo. "Penerapan Desentralisasi Asimetris Dalam Penyelenggaraan Urusan Keistimewaan Daerah Istimewa Yogyakarta Sebagai Basis Otonomi Bagi Terwujudnya Kesejahteraan Rakyat." Cakrawala Hukum IX, no. 1 (2015): 120-51.

Tanjung, Laksmi Nurita, Dyah Mutiarin, and Eko Priyo Purnomo. "Monitoring Dan Evaluasi Pemanfaatan Dana Keistimewaan Daerah Istimewa Yogyakarta Tahun 2013. 2017." Jurnal Agregasi 6, no. 1 (2018): 60-91. tirto.id. "Untung Pakualaman Di Tengah Nasib Buntung Petani Dari Proyek NYIA.” tirto. id, 2018. 
tribunnews.com. "Ichlasul Amal Didemo Massa

Propenetapan." tribunnews.com, 2010.

viva.co.id. "HB X: Warga Tak Berhak Usir

George Aditjondro." viva.co.id, 2012.

_. "Rumah Ichlasul Amal Didemo." viva. co.id, 2010.

Widyatama, Bastian. "Applying Kingdom's

Multiple Streams Framework in the Establishment of Law No. 13 of 2012 Concerning the Privilege of Yogyakarta Special Region." Journal of Government and Civil Society 2, no. 1 (2018): 1-18.

Witono, Banu, Eko Ganis Sukoharsono, Roekhudin, and Nurkholis. "Hegemony Construction Of Local Government Financial Accountability In Indonesia." International Journal Of Scientific $\mathcal{E}$ Technology Research 8, no. 12 (2019): 40413.

Yalvac, Faruk, and Jonathan Joseph. "Understanding Populist Politics in Turkey: A Hegemonic Depth Approach." Review of International Studies, 2019, 1-19.

Yudhatama, Iranda. "Komunikasi Politik Dan Partisipasi Warga Dalam Arena Perencanaan Dan Penganggaran Dana Keistimewaan DIY." Jurnal Ilmu Komunikasi 15, no. 3 (2017): 205-14. 